\title{
Christianity and Human Rights
}

\author{
HaRold B. KUHN
}

There are few subjects upon which it is more difficult to please all readers than that of Human Rights. While nearly everyone believes that there are certain rights which are "fundamental" there is little agreement upon precisely what basis these precious rights are fundamental. In general, there are three major approaches to the subject. The first is that human rights represent the merely experimental or positive experience of evolving man. The second seeks to ground human rights almost wholly in what is called 'Natural Law' and thus see man's rights as inalienable to man simply because he is man. The third, while recognizing the basic validity of Natural Law, feel that human rights proceed more directly from the God of Grace, so that an explicit recognition of the divine sovereignty in human life is a sine qua non of a society which gives due place to the dignity and rights of man.

It may be said, in brief, that the first of these is naturalistic, the second metaphysical and formalistic, the third theological. The subject in hand divides itself rather easily into two parts: first, upon what basis do human rights rest?; and second, what rights may be considered proper and inalienable to man?

I.

The naturalistic or positivistic approach to the subject is the child of the evolutionary philosophy, and which makes morality to inhere in the folk-ways of the human community. Legal codes become little or nothing more than the codified mores of the social group. The moral becomes the legal. Human rights are, to this view, discoverable by rummaging through parchments and the literature of the past. Trial-and-error becomes the source of both that which is legal and that which is right. One jurist expresses this position in the following words:

And so, if I am to say what are "the principles of civil liberties and human rights," I will answer that they lie in habits, customs-conventions if you will-that tolerate dissent and can live without irrefragible certainties...1

1 Judge Learned Hand, "A Fanfare for Prometheus" in Vital Speeches, March 1, 1955, p. 1074. 
This doctrine is open to grave objections. If the rights of man are merely positive (i.e., resting upon use or custom), then any course of conduct may be made right by statute. This is precisely what the dictators have assumed as a basis for their conduct. The problem arises at once, however, whether a simple appeal to usage may not show that the most perverse and the most brutal type of practice have been found to be acceptable in some society.

It is small wonder that a Justice of our Supreme Court has wryly remarked that the contemporary interpretation of civil rights in our day has been made difficult by the body of positive decisions of the past century, made under the impact of a century in which evolutionism and naturalism have been largely dominant in our national life. Small wonder that jurisprudence is today seeking a new insight into "first principles" of morality. Further, the hammerblows of Fascist and Communist tyranny have compelled an "experimental' West to give sober pause. At Nürnberg, western man was brought face to face with the real consequences of a naturalistic and a moral jurisprudence. And in spite of the cynicism with which the work of Justice Jackson and his associates has been viewed, the Nürnberg Trials did seek to restore a moral foundation to western Law.

Communist dogma, with its assumption of a materialistic dynamism behind all of life, and its twin assumption of the complete malleability of human nature, has from the first assumed that law and right are of positive origin, and that morality and convenience are one. Its omnipotent State becomes the highest and final source of human rights. The will and fiat of that State may shape, alter, revoke or revise the right of any man at any time. This is the reductio ad absurdum of a philosophy of man completely divorced from his origin in a divine creation.

The second approach to the source of human rights is that which sees them as grounded in Natural Law. At the outset, some will dismiss this with the wave of the hand, suggesting that Natural Law is a vaporous concept, an abstraction understood only by the detached jurist or the theologian who lives in an ivory tower, out of touch with the realities of life. There is no doubt some justification for this objection, for it seems to the outsider that the Roman Pontiff, when he has no better argument to support his case for some course of action, often turns his argument upon some appeal to his interpretation of Natural Law. However, to toss out the baby 
with the bath would be folly; and certainly God created man before the State, or before legal codes existed. Out of the relationship set up in Creation, human rights did appear.

In seeking to discover in what sense certain human rights are 'fundamental,' scholars and jurists are endeavoring to break out of the positivistic routine, and to ground morality and right beyond the reach of mere convention or utility. The most conspicuous example of this type of thinking concerning human rights is that of the framers of the American Declaration of Independence. One is amazed at the coolness and restraint of such men as Thomas Jefferson. Writing in the midst of fundamental abuses and grievances, and with war a certainty, he and his colleagues could write: "We hold these truths to be self-evident, that all men are created equal, that they are endowed by their Creator with certain inalienable rights, that among these are life, liberty, and the pursuit of happiness."

George Sokolsky rightly observes:

It must seem curious that the revolutionists of 1776 wrote such a declaration at all. Why did they go to all the trouble of basing their claims for independence upon a philosophy of life? Why did they not shriek:

"Down with the king!"

"Hang King George III!"

"No taxation without representation."

"Murder the tax collectors!"

"All power to the workers and peasants!"

"Kill the priests!"

Similar slogans have been the battle cries of revolutions from Spartacus to Lenin.2

What a contrast between such an hypothetical pronouncement and the calm with which the Declaration of Independence was framed. It may be said that this was the fundamental difference between the American Revolution and that of France, or of most of the European revolutions since that time. It is as different as day is different from night, from the wording of the Communist Manifesto: struggles.

The history of all hitherto existing society is the history of class

Freeman and slave, patricial and plebian, lord and serf, guild-master

2 Barrett, Edward F. (Ed.) Natural Law Institute Proceedings, Volume IV, 1950. 
and journeyman, in a word, oppressor and oppressed, stood in constant opposition to one another, carried on an ... open fight ...

Let the ruling classes tremble at a Communist revolution. The proletarians have nothing to lose but their chains. They have a world to win.

The contrasts between the two ways of doing things are both numerous and obvious. Note, first, the reverent tone of the Declaration of Independence. Basic is the recognition of the Creatorcreated relationship. Some may and do object, that the framers, especially Franklin and Jefferson, were deists, and that the Declaration really suggests that God set the world of humans in motion, and left them to work out their own ways. While there may be some plausibility to this argument, it is not necessarily the final word on the subject. In other words, it is possible that deism and theism overlap at this point, and that a deist may lay hold upon some principles central and significant for a theistic interpretation of things.

The pronouncements of the founders of our nation thus reflect the after-glow of Puritanism, with its insistence upon the divine sovereignty and its firm convictions upon the subject of the origin and destiny of human life. The rigors of 150 years on the new continent had kept the colonists from falling under bondage to things and to material comfort. They retained, in the midst of a regrettable loss of much of the content of a great theology, a reliance upon divine guidance. Their eyes were still upon the laws of God, rather than upon the dictates of sovereigns or of parliaments. They retained a Puritan willingness to rest their political case-and their personal fortunes-upon God's law, staking all upon the proposition that God had revealed His law in His creative work. Thus, they assumed as self-evident, that there is an unchangeable truth, which, being the expression of nature's God, is applicable in all circumstances and to all cases.

It is the contention of the advocates of the theistic view of human rights, that the appeal to Natural Law is valid as far as it goes. That is, the appeal to natural law is correct in its assumption that there is a standard of right and wrong which is antecedent to positive law, and that God was the source of this standard. What is questioned is, whether this position can maintain itself without more explicit reference to an adequate Christian theology. In other words, it is questioned whether there is not a damaging ambiguity in the deistic position which rests its case merely upon God's activ- 
ity in creation, by which human rights may be misinterpreted as being inherent in man, rather than conferred upon him.

The crux of the question at this point is, the extent to which man is continually reliant upon his Maker. There is a rather vigorous tendency in our day to transpose the source of human rights to a humanistic basis. Some are explicit in writing that Christian principles had far less influence upon the Men of 1776 than is commonly supposed, and that in their reference to "nature's God" they were actually protesting the theistic position with the best weapons then at hand. This does not affect the real validity of the work of the framers. It does highlight the position which asserts that an adequate view of human rights as proceeding from God requires for its maintenance and nourishment the full position of historic Christian theism, in which the doctrines of divine sovereignty and divine providence are given large recognition.

A large source of the tragedy of the twentieth century is the prevalence of a pragmatic philosophy which seeks to supersede all positions which rest upon eternal and unchangeable truth. This positivistic spirit is hostile to the principles of Natural Law, but finds it easier to cope with a view which rests upon the rather remote conception of "nature's God" than with the assertions of a theism which holds that God upholds all things by the word of His power, that $\mathrm{He}$ is Lord of nations of history, and that the times of all men are in His hand. Our democracy, based as it is upon natural law, is a way of life which rests upon something more than the forms of the religious life. It is based, ultimately, upon men and women whose high views of civic morality and civic responsibility are the outcroppings of a devout recognition of the active operation of God in human life. How long it can maintain itself, as a corporate expression of confidence in the rights of man, in the face of the dwindling of this recognition, one cannot say.

\section{II.}

With respect to the question of which rights are proper and inalienable to man, an article of this length cannot be expected to do more than to enumerate the rights which are held to be revealed by Natural Law, to relate them to the principles of the Christian Faith, and then to examine in a brief fashion the contemporary tendency to expand the list of 'rights.'

The Framers of the Declaration of Independence showed a 
remarkable restraint in their enumeration of the rights which were deemed to be the direct endowment of man from his Creator. These were indicated to be basically three: life, liberty, and the pursuit of happiness. Essentially, these are political and civil in character, and were of such a nature as to imply basically an absence of capricious and repressive activity upon the part of the State. Life was to be protected against the destructive whims of rulers and magistrates, who were after all such only by the consent of the governed. The right of liberty was 'natural' in that it belonged to the nature of man as created in the image of God. The right to 'the pursuit of happiness' was basically the right to pursue that which was the proper function of man as from the divine hand-even though the Fall may have distorted his view, and confused him with respect the basic questions of ends-and-means.

The power of life and death was exercised by the Roman pater familias over his offspring; he retained to himself the decision whether a child should be permitted to survive or not. The Roman Empire assumed this right over its subjects; and it has been a long struggle through which the right to life has been wrested from ambitious and power-mad rulers. In our own time, dictators who spoke as symbols of omnipotent States, still challenge the right of the individual to life. Today, the right to life is challenged on a wide scale and in the grand manner. The Nazi leaders gave a modern turn to mass murder, in the form of the crime of genocide-the murder of entire racial groups. It is ironic that the Convention against genocide is for the moment favored by a nation which openly professes to be at war-unto-death against entire classes of men, and has sworn to stop nowhere short of the liquidation of any and every group which stands in its way. Such cynicism is, of course, the ultimate in positivism, which denies fixed points in civic morality.

Basically, the right to life is the right to continue living, under conditions conducive to it, so long as the Lord of life permits. Only under the most grave circumstances, such as in case of high crime, may the State be held justified in terminating human life, or in permitting any group within society to do so. Sensitive Christians have seldom been able to consent, in the name of humanity, to legalized euthanasia, even though death so administered might prevent grave suffering. When the basic quality of human life is recognized: namely that human life on earth is probationary for eternity-then 
none will assume easily the prerogatives belonging to the Lord of life and death.

The right to liberty is one whose elaboration could occupy volumes. The most that can be done here is to note its most general character. A traditional definition is, that liberty is the absence of compulsive restraint toward a given course of action. Thus, in a 'free' situation, the individual is able to act in either one way or in another, in the presence of all the elements of proper determination. It does not, of course, mean the absence of obligation or of accountability. It implies, as an absolute essential, that the individual is free to work out his destiny. And it is the obligation of the State to provide the framework within which that destiny-which reaches beyond time-may be fulfilled. Such liberty implies freedom of choice, freedom of conscience, freedom of worship, and freedom from unnecessary constraint, beyond that which is essential to the maintenance of a 'society under God.'

It is by no means easy to define the precise manner in which civil government proceeds from God. It is, however, the conviction of many of us that the democratic form of government as it has been developed in the West under the stimulus of Natural Law affords the best conditions under which men may exercise liberty in the fulfillment of their ultimate destinies. We must emphasize here, that governments or constitutions do not confer liberty; when and as they fulfill their duty in this respect, they recognize, protect and enjoin it, and guard the means to its attainment.

The right to the pursuit of happiness is likewise one whose exposition involves many by-paths. The very definition of "happiness' has puzzled thinkers for a long time. Augustine found two hundred eighty-eight such definitions current in his time. Most sensitive individuals have abandoned at the outset the view that happiness lies in sensual enjoyment, whether active or passive. While Aristotle rejected the old equation of happiness with sensepleasure, his metaphysical definition, that "Happiness is a bringing of the soul to act according to the habit of the best and most perfect virtue," is much too cold. The divorce of philosophy from theology in the early Modern Period led to a narrowing of the definition of happiness to mere temporal felicity. In the light of this, it should be held in mind that happiness here is intimately related to beatitude in the world to come, since the latter may be anticipated and in some limited measure be enjoyed here. 
It is most important to note that happiness in this life is always relative and incomplete. All men seek it by nature; in a world of competing interests and of numerous contingencies, not all find it. Certainly none are entitled to do so at the expense of the violation of the rights of others. Positivistic approaches to man's right to happiness usually conceive of man in material terms, and thus restrict the 'pursuit of happiness' to his adjustment to environment. Deeper views of human rights, particularly the theistic view, recognize that man is a creature of both body and spirit, and whose destination is eternity. It is only in this light that the question of the pursuit of happiness comes into focus, so that even the problems which besiege us on all sides begin to make sense. The duty of the State is to provide the environment in terms of which men will, at the highest level which they choose, seek for well-being. And it is the function of the Christian Faith to point them to that highest level, as it is found in the appropriation of the Grace of our Lord.

Two tendencies appear in the contemporary discussion of human rights. The first is, to multiply the number, so as to include among them not only civil and political rights, but economic and social rights as well. The second is, to consider human rights as conferred by a government, or by an international super-government. With reference to the first of these tendencies, it should be said that it parallels the tendency of governments to reach further and further into the affairs of its citizens, and to offer security as a substitute for historic freedoms. Guided by doctrinaire notions of property ownership, the newer 'liberal' movements create a false antithesis between 'property rights' and 'human rights.'

This is a part of the evil logic of Marxism, which not only recognizes the irreconcilable opposition between its dogma and the natural desire to acquire and own property, but which capitalizes upon the conflicts which its adoption will set up. It is the view of many, that limited constitutional government affords the best possible interplay between human social justice and the 'human right in property.' Those who would extend the field of human rights so as to include any and all forms of temporal and economic security may well find themselves finally enmeshed in the welfare state, which finds civil and political repression essential to the achievement of what it cynically calls 'economic democracy.'

The second tendency, namely that of considering human rights as originating in government, and maintained by its genial largesse, 
is what one may expect from an international movement which attempts to include within its membership both free nations and dictatorships, both communities acknowledging the God of the Bible and those who acknowledge another god or none at all. There is good reason to fear that international cooperation in the field of human rights, such as that which has been proposed by the United Nations' Universal Declaration of Human Rights, must reduce such theory and practice to the dead level of pragmatic principles of right and wrong. "Rights" become the donation of the organization, revocable at its whim. Some will doubtless dismiss such a statement as the result of "a lack of global thinking." No thinking person would wish to stand in the way of an improvement of the conditions which oppress the vast majorities of men and women, certainly not in the name of a blind and unyielding conservatism. However, idealisms should not blind Christians in this land to the point at which they would be willing to surrender our national heritage to an Organization whose common denominator in the question at hand is that of a humanistic pragmatism.

If our nation, with its unsought rôle of leadership in world affairs, cannot succeed in projecting its fundamental principles into the councils of the United Nations Organization, it should do some heart-searching. Should it find itself lacking in moral force to do so, it should at once seek a return to the source of its former dynamic. Should it, on the other hand, find itself outvoted by those committed to alien principles, then it should think at least twice before yielding its basic heritage in return for some problematic form of a 'brave new world.' Evangelicals may well ponder their responsibility for stimulating such a self-examination. 